\title{
Demand Model of China's Outbound Tourist
}

\author{
Yunita Ismail Masjud \\ yunitaismail@president.ac.id \\ Engineering Faculty, Universitas Presiden, Cikarang, Indonesia
}

\begin{abstract}
This research objective was to find out the impact of resident income, tourism prices, exchange rate, and bilateral trade in goods towards China's outbound tourism trips. This research used the data from research that done by Yi (2018) and used the China Statistical Yearbook to obtained bilateral trade volume and total number of domestic trips from 20062015. Panel data in multiple regression model was used to analyzed the outbound tourism demand in China. The results showed that all variables had significant influence partially towards China's outbound tourist trips, except travel price. Simultaneously all variables had significant influence towards China's outbound tourist trips.
\end{abstract}

Keywords: China's outbound tourism demand, resident income, tourism prices, exchange rate, bilateral trade volume

\begin{abstract}
Abstrak
Tujuan penelitian ini adalah untuk mengetahui dampak dari pendapatan penduduk, harga pariwisata, nilai tukar, dan perdagangan barang bilateral terhadap perjalanan wisata outbound Tiongkok. Penelitian ini menggunakan data dari penelitian yang dilakukan oleh Yi (2018). Selain itu, data juga diperoleh dari China Statistical Yearbook untuk memperoleh volume perdagangan bilateral dan jumlah total perjalanan domestik dari 2006-2015. Data panel dengan model regresi berganda digunakan untuk menganalisis permintaan pariwisata outbound di Tiongkok. Hasil penelitian menunjukkan bahwa semua variabel memiliki pengaruh signifikan secara parsial terhadap perjalanan wisata outbound Tiongkok, kecuali harga perjalanan. Secara bersamaan semua variabel memiliki pengaruh yang signifikan terhadap perjalanan wisata outbound Tiongkok.
\end{abstract}

Kata kunci: permintaan pariwisata outbound China, pendapatan penduduk, harga pariwisata, nilai tukar, volume perdagangan bilateral

\section{INTRODUCTION}

Outbound tourism of China refers to the Chinese people traveling to other countries for vacation. In 2019, China's outbound tourism based on National Migration Administration of China was 6,311 million, increased by 12.48 percent over the same period of 2018 (https://www.travelchinaguide.com/tourism/2019statistics/). In 2018, China outbound tourist arrivals totaled 149.72 million, and mostly from 10 top sources cities, which are Shanghai, Beijing, Guangzhou, Chengdu, Nanjing, Kunming, Wuhan, Xi'an, and Hangzhou. The 10 top destinations are Thailand, Japan, Vietnam, Singapore, Indonesia, Malaysia, United States of 
America, Cambodia, Russia, and Philippines (travelchinaguide.com). As an example, based on China Statistical Yearbook, 2019, on January and February 2019, increasing rate over the same time of 2018, from Shanghai to Hong Kong is $148.12 \%$, to Macau $46.63 \%$.

Figure 1. that showed the number of Chinese outbound tourists reached 16.1 billion in 2018, while in 2009 just 4.7 billion (www.data.stats.gov.cn, 2018). In the past ten years, the number of outbound tourists from China has increased significantly. However, as Figure 2. showed, the growth rate has declined until 2017 and increased since that. These could be because of the devaluation of the renminbi, the fluctuation of the social environment, the frequent occurrence of terrorist attacks, and the suppression of outbound travel preferences.

With the further expansion of China's outbound tourism market scale and the advancement of China's outbound tourism practice, the current research on China's outbound tourism focuses on whether development is excessive or outbound tourism policies. The development of China's outbound tourism needs to consider the macroeconomic factors.

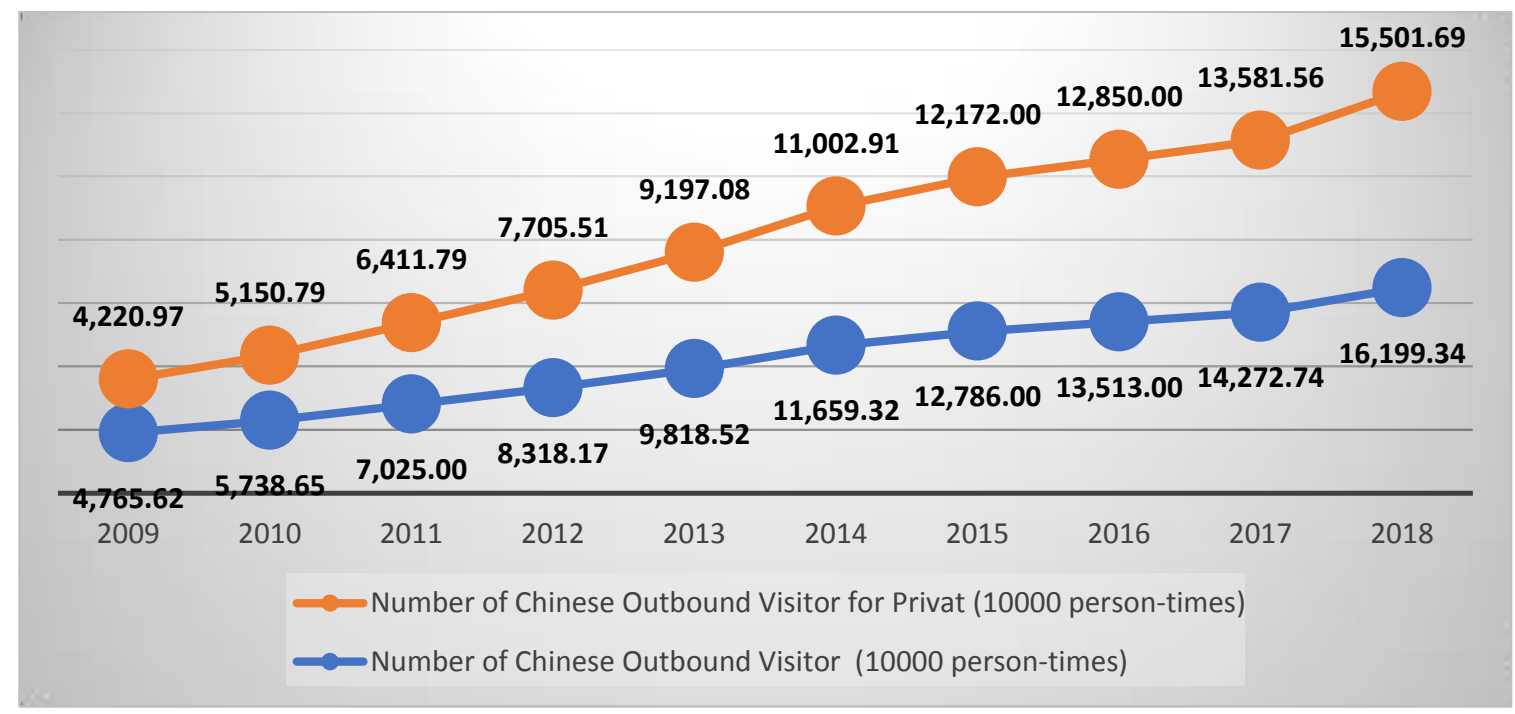

Figure 1. China's outbound tourist trips 2014-2017

Source: Adjusted from NATIONAL DATA( www.data.stats.gov.cn ), 2018

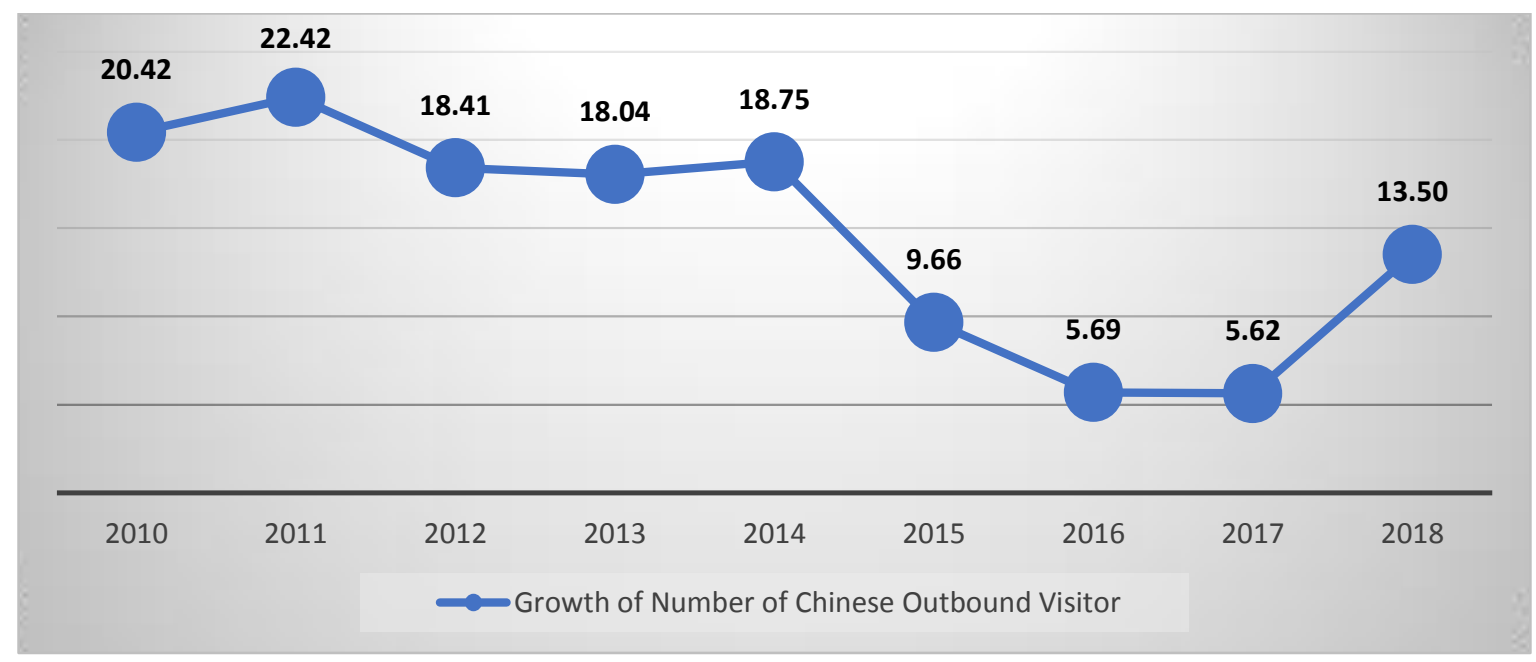

Figure 2. China's Outbound Tourist Trips Growth Rate (\%) Source: Adjusted from NATIONAL DATA( www.data.stats.gov.cn ), 2018 
In this article, the objectives were to find out the influence of resident income, tourism prices, exchange rates, and bilateral trade volume towards China's outbound tourist trips partially and simultaneously.

\section{LITERATURE REVIEW}

China's outbound tourism trips refer to travel to another country within a unit time. China's outbound trip could showed the demand of China tourism by people from the other countries. The number of trips includes the total number of people who repeat a trip to a certain place within the unit time (Wenying, Wang \& Zhang, 2014). China's outbound tourism market as the research objects, and summarizes the development characteristics and influencing factors of China's outbound tourism market at various stages (Zhang, 2010). According to Song, Gang Li and Stephen, 2010, the determinant for tourism demand at Hong Kong were tourism income, habit persistence and tourism price. By seeing the determinants of China's outbound tourism trip, that will provide useful inspiration for the sustained and healthy development of China's outbound travel market.

In this research, the first determinant was resident income (Hor, 2015; Song, Gang Li and Stephen, 2010). Resident income refers to the sum of values created by workers in the material production department of a country in a certain period of time. Income is a key factor driving people's travel abroad and chooses GDP per capita as resident income.

The second determinant was tourism price. In economic theory, price is one of the most important factors that affect the demand for goods, and tourism prices are also very important factors. Tourism prices have a negative relationship with travel demand (Song, 2010). According to $\mathrm{Li}, 2015$, it is impossible to obtain or calculate the relevant data of the consumer price index of tourist products purchased by tourists during tourism. The destination consumer price index could be used as a proxy to indicate that tourists cost of living at the destination. However, the destination consumer price index does not always reflect the cost of living for tourists at the destination, especially for international tourism. The consumer price index needs to be adjusted by exchange rate, and it could be used as a viable indicator for tourism price.

The next determinant was exchange rate (Liu, 2018). The exchange rate refers to the ratio or the price of a country's currency to another country's currency, or the price of another country's currency in a country's currency. The theoretical model of international tourism demand based on the real exchange rates and residents' income levels, the panel data of China's 15 major source countries and 11 major destination countries have been analyzed. Income and real exchange rates are the most important factors in determining the inbound and outbound tourism markets, which can explain most of the fluctuations in the international tourism market. Different countries' differing effects on the exchange rate, and happen in RMB exchange rate too (Fan \& Zhang, 2014).

International tourism and international trade have their similarities, and they will cause the international flow, such as flow of people, capital, and goods. Bilateral trade volume would impact the outbound tourism. International trade leads to the international movement of goods and capital, and international tourism; it is the international flow of people, funds too. The rapid economic growth and large scale, and the increasing international trade have promoted the development of inbound tourism, and believed that there is a causal and interactive relationship between international tourism and international trade (Stone et al., 2015). 
In this research, the four independents are resident's income, tourism price, exchange rate and bilateral trade volume, and the dependent variable is China's outbound tourist trips. Developing the hypothesis is about the influenced of each independent variable (resident's income, tourism price, exchange rate and bilateral trade volume) toward dependent variable (China's outbound tourist trips) partially and simultaneously.

\section{RESEARCH METHOD}

This research data come from the data of China Outbound Tourism Development Annual Report 2006 to 2015 and data on 19 major outbound travel destinations of Chinese tourists from 2006 to 2015. The destination countries were the United States, Britain, Turkey, Russia, Singapore, Indonesia, Thailand, Philippines, New Zealand, Netherlands, Malaysia, South Korea, Japan, India, Germany, France, Canada, Brazil, and Australia. The number of outbound tourists in China comes from the Tourism Statistical Yearbook issued by the World Tourism Organization; the data on consumer price index (CPI), exchange rate and GDP per capita of various countries come from the WDI database of the World Bank; the bilateral trade volume come from the China Statistical Yearbook (Yi, 2018).

Total samples that used in this research were 190. Data analysis that used was descriptive statistics and multiple regression model. The multiple regression model used with the assumption that each data were independent and the data could be a cross section data. Its specific tourism demand model was constructed as follows:

$$
Y=\beta_{0}+\beta_{1} X_{1}+\beta_{2} X_{2}+\beta_{3} X_{3}+\beta_{4} X_{4}+\varepsilon
$$

Where:

$\mathrm{Y}=$ China's outbound tourist trips

$\beta_{0}=$ The constant

$\beta_{1}=$ The coefficient of Resident Income's

$\mathrm{X}_{1}=$ Resident Income

$\beta_{2}=$ The coefficient of Travel Prices

$\mathrm{X}_{2}=$ Tourism Prices

$\beta_{3}=$ The coefficient of Exchange Rates

$\mathrm{X}_{3}=$ Currency Rates

$\beta_{4}=$ The coefficient of Bilateral Trade in goods

$\mathrm{X}_{4}=$ Bilateral Trade in goods

$\varepsilon=$ Random error

After constructing the linier regression model, proceed to clasical asumption test. The clasical asumption test were normality test using histogram, heteroscedasticity test using scaterred plot and multicollinierity test using VIF test. Answering the hypothesis 1 until 4 used $\mathrm{t}$ test and for hypothesis 5 used $\mathrm{F}$ test. Goodness of fit of the model tested by classical asumption test and the power of the model showed by coefficient of determination $\left(\mathrm{R}^{2}\right)$.

\section{RESULT AND DISCUSSION}

\section{Descriptive Statistics}

Table 1. Descriptive Statistics

\begin{tabular}{crrr}
\hline & Mean & Std. Deviation & N \\
\hline China's Outbound Trips & 85.71 & 112.908 & 190
\end{tabular}


Resident Income

CPI

$2,7802.96$

Exchange Rate

Bilateral Trade Volume
605.47

$95,840,910.76$

\section{Source: Data Analysis}

The standard deviation values showed the variation and distribution of the data and the interval values of the variables. The mean showed the center measurement of value each variable. From Table 1, the value of standard deviation for data of resident income's and bilateral trade volume, higher compare to its mean. That showed data of resident income's and bilateral trade volume so vary along that period. For tourism price, exchange rate and China's outbound tourist trips, the value of standard deviation showed the data have a longer interval data.

\section{Multiple Regression Model}

Multiple regression model is constructed by using stepwise method in finding the coefficient. By using this method, the construct model could be used for prediction. The result for multiple regression model showing in Table 2 with 3 calculation process to find the best model.

First calculation used one variable, which is bilateral trade volume; proceed to next calculation with two variables, which are bilateral trade volume and CPI, and the last calculation with three variables, which are bilateral trade volume, CPI and resident income. Variable exchange rate did not used, because this variable is not significant in this model. So, the multiple regression model was:

\section{China's Outbound Trips $=144.789+4.526 E-007$ Bilateral Trade Volume - 12.903 CPI - 0.002 Resident Income}

From the model, China's outbound trips had positive relationship with bilateral trade volume and had negative relationship with CPI and resident income. The increased of bilateral trade volume would increase the China's outbound trips and the increased of CPI or resident income would decrease the China's outbound trips.

To find the goodness of fit model, this multiple regression model proceed to the classical assumption test. For normality test used histogram that could show that the distribution of errors from this model would normally distributed. The normal distribution of errors would show that the error of this model is still in fix range. Histogram of errors model showed at Figure 3.

Table 2. Multiple Regression Model with Stepwise Method

\begin{tabular}{|c|c|c|c|c|c|c|c|}
\hline Model & B & $\begin{array}{l}\text { Std. } \\
\text { Error }\end{array}$ & Beta & $\mathrm{t}$ & Sig. & $\begin{array}{l}\text { Toler } \\
\text { ance }\end{array}$ & VIF \\
\hline (Constant) & 43.971 & 10.125 & & 4.343 & .000 & & \\
\hline $\begin{array}{c}\text { Bilateral } \\
\text { Trade Volume }\end{array}$ & $4.355 \mathrm{E}-007$ & .000 & .408 & 6.133 & .000 & 1.000 & 1.000 \\
\hline (Constant) & 71.379 & 14.944 & & 4.776 & .000 & & \\
\hline $\begin{array}{c}\text { Bilateral } \\
\text { Trade Volume }\end{array}$ & 3.799E-007 & . 000 & .356 & 5.161 & .000 & .906 & 1.104 \\
\hline $\begin{array}{l}\text { CPI } \\
\text { (Constant) }\end{array}$ & $\begin{array}{r}-6.143 \\
144.789\end{array}$ & $\begin{array}{r}2.491 \\
21.845\end{array}$ & -.170 & $\begin{array}{r}-2.466 \\
6.628\end{array}$ & $\begin{array}{l}.015 \\
.000\end{array}$ & 906 & 1.104 \\
\hline $\begin{array}{l}\text { Bilateral } \\
\text { Trade Volume }\end{array}$ & $4.526 \mathrm{E}-007$ & .000 & .424 & 6.280 & .000 & .859 & 1.164 \\
\hline CPI & -12.903 & 2.822 & -.358 & -4.572 & .000 & 642 & 1.558 \\
\hline
\end{tabular}

DOI: http://dx.doi.org/10.33021/jaaf.v3i2.810 


\begin{tabular}{cccccccc}
\hline $\begin{array}{c}\text { Resident } \\
\begin{array}{c}\text { Income } \\
\text { a. Dependent Variable: }\end{array} \\
\text { China's Outbound Trips }\end{array}$ & -.002 & .000 & -.353 & -4.434 & .000 & .619 & 1.617 \\
\hline
\end{tabular}

Source: Data Analysis

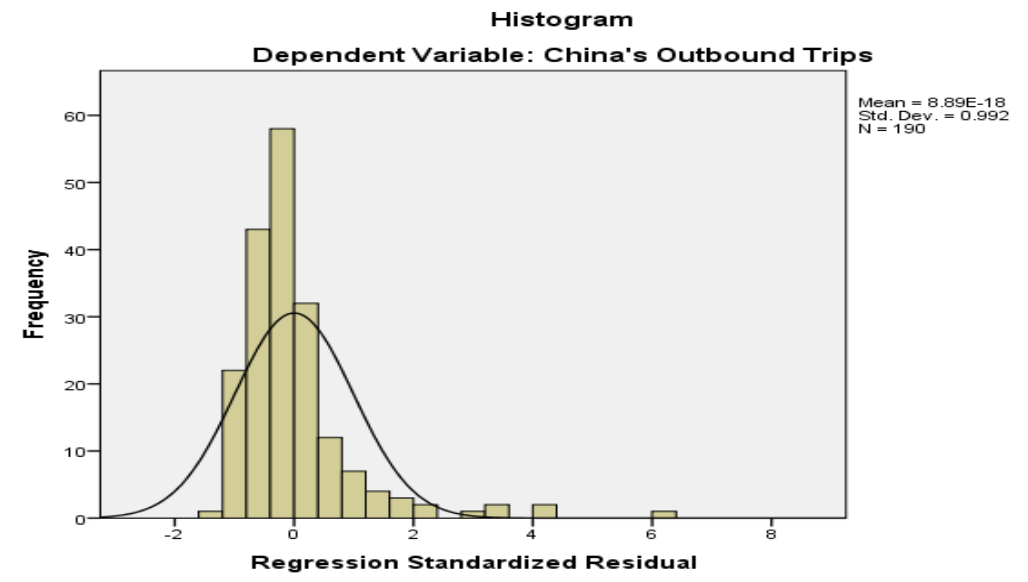

Figure 3. Histogram for Normality Test

Source: Data Analysis

From Figure 3, shown the errors of this model distributed follow that bell shape. It means the errors had normally distribution.

The second test was heteroscedasticity test. This test showed the errors of the multiple regression model would vary in random way, did not have a pattern. The heteroscedasticity test shown by Figure 4 . Figure 4 did not showed any pattern, so the model past the heteroscedasticity test.

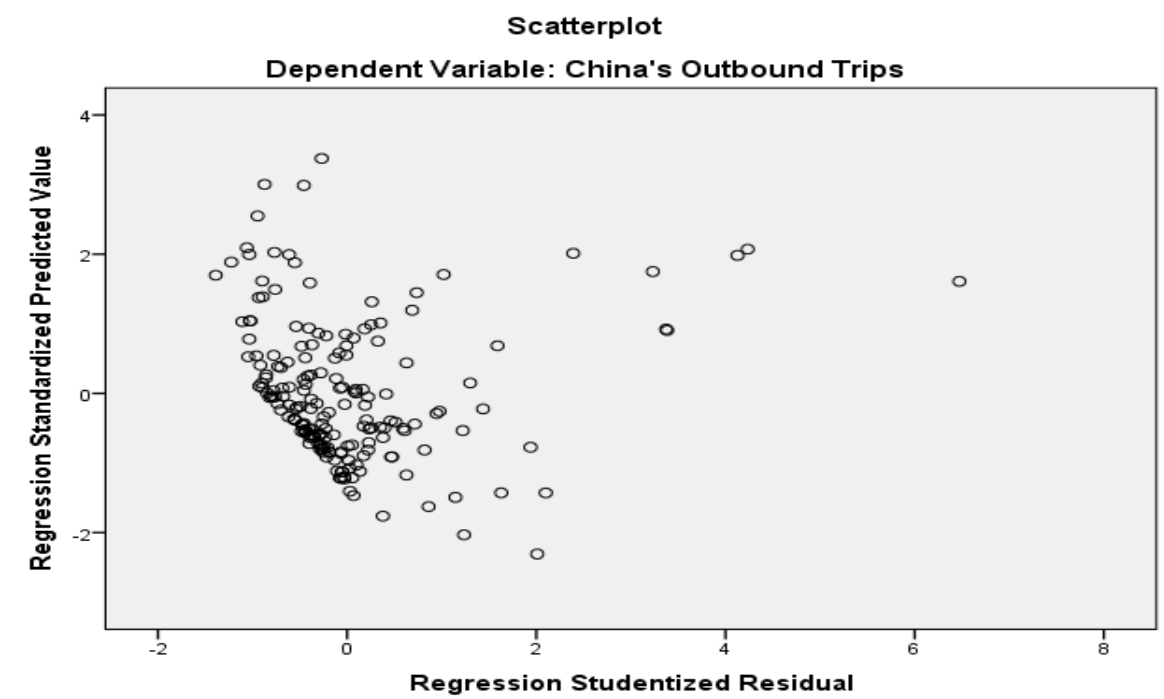

Figure 4. Scatterplot for heteroscedasticity Test

Source: Data Analysis

The last test for the model was multicollinearity test. This test would show that the independent variables in this model would influenced the dependent variable by itself or no interaction among them. The test for multicollinearity used VIF (see Table 2) with value less than 10 showed no multicollinearity in this model, and the value of VIF for each variables were less than 10. 
The multiple regression model pasted for all classical assumption test, and could be used for hypothesis testing. From Table 2, all p-value of all independent variables were less than 0.05 (as a level of significance). It means, all independent variables, including the constant had a significant influence toward China's outbound tourist trip. The bilateral trade volume, CPI and resident income had a significance influenced toward China's outbound tourist trip.

The result of $\mathrm{F}$ test shown at Table 3. The $\mathrm{F}$ test running for three constructed equation and showed that simultaneously all independent variables (bilateral trade volume, CPI and resident income) had significant influence toward the China's outbound trips, with significance value $0.000(<0.05)$.

Adjusted R square (Table 4) showed that the variation of dependent variables could be explained by the variation of all independent variables. From Table 4, the variation of variable China's outbound tourist trip could explained only 25.8 percent by variable bilateral trade volume, tourism price, and resident income another 74.2 percent variation explained by other variables. This model is not a really good model, but this model could show the significant influence of independents variables toward the dependent variable.

Table 3. F Test Result $\left(\mathrm{ANOVA}^{\mathrm{a}}\right)$

\begin{tabular}{rlrrrrr}
\hline Model & & \multicolumn{1}{c}{ Sum of } & df & Mean Square & F & Sig. \\
\hline \multirow{2}{*}{1} & Squares & & & & \\
& Regression & 401665.609 & 1 & 401665.609 & 37.611 & $.000^{\text {b }}$ \\
& Residual & 2007757.886 & 188 & 10679.563 & & \\
& Total & 2409423.495 & 189 & & & \\
& Regression & 464913.843 & 2 & 232456.922 & 22.355 & $.000^{\text {c }}$ \\
& Residual & 1944509.652 & 187 & 10398.447 & & \\
& Total & 2409423.495 & 189 & & & \\
& Regression & 650780.350 & 3 & 216926.783 & 22.943 & $.000^{\text {d }}$ \\
& Residual & 1758643.145 & 186 & 9455.071 & & \\
& Total & 2409423.495 & 189 & & & \\
\hline
\end{tabular}

a. Dependent Variable: China's Outbound Trips

b. Predictors: (Constant), Bilateral Trade Volume

c. Predictors: (Constant), Bilateral Trade Volume, CPI

d. Predictors: (Constant), Bilateral Trade Volume, CPI, Resident Income

Source: Data Analysis

Table 4. $\mathrm{R}^{2}$ Results (Model Summary ${ }^{\mathrm{d}}$ )

\begin{tabular}{|c|c|c|c|c|}
\hline Model & $\mathrm{R}$ & R Square & $\begin{array}{l}\text { Adjusted R } \\
\text { Square }\end{array}$ & $\begin{array}{l}\text { Std. Error of } \\
\text { the Estimate }\end{array}$ \\
\hline 1 & $.408^{\mathrm{a}}$ & .167 & .162 & 103.342 \\
\hline 2 & $.439^{\mathrm{b}}$ & .193 & .184 & 101.973 \\
\hline 3 & $.520^{\mathrm{c}}$ & .270 & .258 & 97.237 \\
\hline
\end{tabular}

a. Predictors: (Constant), Bilateral Trade Volume

b. Predictors: (Constant), Bilateral Trade Volume, CPI

c. Predictors: (Constant), Bilateral Trade Volume, CPI, Resident Income

d. Dependent Variable: China's Outbound Trips

Source: Data Analysis 


\section{Discussion}

The model in this research consists of three independent variables, which were bilateral trade volume, CPI (Tourism price) and resident income. The bilateral trade volume showed international tourism that was a flow of people, fund, etc. caused by goods or labor (Kadir, 2010). Bilateral trade volume could act as a promotion for the country. According to Stone, $\mathrm{Xu} \&$ Shen, 2015, China's import and export trade had a clear role promoting outbound Russian tourism, the role of the import trade to promote a little bit stronger. Increasing bilateral trade volume, meaning the promotion on outbound tourism would be increased, and would increase the China's outbound tourist trip too.

Tourism price actually would the same with price of commodity, based on demand theory, price will have negative relationship with quantity of demand. In this research, tourism price calculated by using consumer price index (CPI), and because this is an outbound tourism, CPI adjusted by exchange rate ( $\mathrm{Li}, 2015)$. Consumer price index divided by exchange rate gave the ability of tourist to spend their money at the destination place. Increasing the ability of tourist to spend their money would make the increasing outbound travelling.

Resident income had a significant influence toward China's outbound tourist trip with negative relationship. In this research, resident income calculated from GDP per capita at constant prices for 2016. For outbound tourism, resident would need more budget rather than for inbound trip. According to Qing \& Sun, 2014, if the GDP per capita exceeded 20,000 US dollar, the resident chose long-distance intercontinental travel opportunities to increase, while short-distance intra-continental tourism was relatively stable, and status quo of China's outbound tourism revenue. That was an explanation for negative relationship between resident income and China's outbound tourist trip too. The resident that had income lower than 20,000 US dollar did not consider to outbound travel, until their income reached 20,000 US dollar or more.

\section{CONCLUSION}

The conclusion for this research were bilateral trade volume, tourism price (CPI) and resident income had a significant influence toward China's outbound trips partially and simultaneously. Exchange rate did not have significant influence toward China's outbound trips.

\section{REFERENCES}

Hor, C. 2015. Modelling International Tourism Demand in Cambodia: ARDL Model. Review of Integrative Business \& Economics Research. 4(4).

Kadir, N. 2010. The Cointegration and Causality Tests Tourism and Trade In Malaysia. International Journal of Economies and Finance. 2.

Li, L. 2015. Research on the Development Trend and Demand Influence Factors of China Outbound Tourism Market. Guangxi University.

Liu, H. 2018. The Analysis of the Influence Factors of China's Outbound Tourism Market. MATEC Web of Conference 228, 05004. CAS 2018.

Qing, F. \& Sun G. 2014. Models of Income Driven National Outbound Tourism: Comparison of Four Countries and Regions. Journal of Economics and Management. 11(2).

Song, H., Gang L., \& Stephen F. W. 2010. Tourism Demand Modelling and Forecasting: How should Demand be Measured? Tourism Economic, 16 (1). 
Stone, Z., Xu H., \& Shen J. 2015. An Empirical Research on the Interactive Relationship Between China's and Russia's Bilateral Tourism and Import and Export Trade. Human Geography. 8.

Yi, L. 2018. Analysis of China's Outbound Tourist Demand Model. Skripsi. (Unpublished). President University.

Wenying, C., Fan R. \& Zhang H. 2014. Impact of Rmb Exchange Rate Changes on China's Entry-Exit Tourism Market - Analysis Based on Panel Data of Major Source Countries and Destination Countries. Exploration of Economic Problems, 6.

Wenying, C., Wang H. \& Zhang H., 2014. Trends in the Demand for International Outbound Travel under the Influence of Real Exchange Rates and Income: An Analysis Based on Panel Data from 55 Countries. Economic Management. 36(3)

Zhang, C., 2010. Research on China's Outbound Tourism Market Development and Influencing Factors. Tourism Journal.

https://www.travelchinaguide.com/tourism/2019statistics/

www.cnki.net

www.stats.gov.cn/tjsj/ndsj/\#

http://data.stats.gov.cn/

Ministry of Culture and Tourism of the People'S Republic of China ,2016 www.cnta.gov.cn/zwgk/lysj/201711/t20171108_846343.shtml

China Statistical Yearbook,2016 www.stats.gov.cn/tjsj/ndsj/2016/indexch.htm

www.ctaweb.org/

http://www2.unwto.org/ 